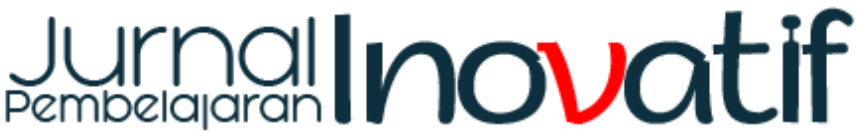 \\ http://journal.unj.ac.id/unj/index.php/jpi
}

\section{Pengembangan Buku Panduan Kredit Pemilikan Rumah Subsdi di PT. Tata Bangun Sarana}

\author{
Sharah Mulyani, ${ }^{\square}$ Suprayekti, Retno Widyaningrum ${ }^{2}$ \\ Sharahmulyaniı@mail.com
}

${ }^{1}$ Universitas Negeri Jakarta, Jakarta, Indonesia.

${ }^{2}$ Universitas Negeri Jakarta, Jakarta, Indonesia.

3 Universitas Negeri Jakarta, Jakarta, Indonesia.

DOI: https://doi.org/10.210o9/JPI.021.05

\begin{abstract}
Article History
Abstrak

Received : 2019

Accepted : 2019

Published : 2019

\section{Keywords}

Keywords 1;

Pengembangan 2;

Buku Panduan 3; KPR

Subsidi 4; Belajar

Mandiri 5. Rowntree

Penelitian pengembangan ini bertujuan menghasilkan buku panduan kredit pemilikan rumah subsidi yang dapat digunakan secara mandiri oleh konsumen di PT Tata Bangun Sarana. Penggunaan buku panduan kredit pemilikan rumah subsidi ini diharapkan mampu membantu konsumen dalam melalui tahapan pengajuan kredit dari tahap booking fee, melengkapi formulir persyaratan, wawancara, observasi/survei sampai dengan proses akad kredit. Penelitian ini menggunakan model pengembangan dari Rowntree yang melalui tiga tahapan yaitu (1) Tahap Perencanaan (2) Tahap Penulisan (3) Tahapan Penulisan dan Penyuntingan. Produk dievaluasi dengan menggunakan evaluasi formatif. Evaluasi formatif yaitu melalui uji coba ahli materi dan ahli media. Hasil yang diperoleh dari uji coba ahli materi adalah 3,7 sedangkan hasil uji coba ahli media adalah 3,37. Evaluasi juga dilakukan kepada konsumen melalui beberapa tahapan yaitu uji coba one to one yang memperoleh hasil 3,56. Kemudian uji coba Small Group Evaluation memperoleh hasil 3,64. Hasil keseluruhan dari semua tahapan uji coba adalah pengembangan buku panduan kredit pemilikan rumah subsidi sudah sangat baik. Buku panduan ini dapat membantu konsumen.
\end{abstract}

Abstract

The purpose of this developmental research is to produce mortgage subsidy guide books that can be studied independently by consumers in PT. Tata Bangun Sarana. The use of mortgage subsidy guide books expected to assist in filing stage through credit, from the stage of the booking fee, complete the requirement forms, obervation/survey, until the process of the contract credit. The research uses development model from Rowntree through three stage: (1) Planing Stage (2) Stages of Writing (3) Stages of Writing and Editing. Product are evaluated using formative. Formative evaluation is through the trial of material experts and media experts. The results obtained from a material expert trial is 3,7 while the trial results a media expert is 3,37. Evaluation is also conducted for consumer through several stages of one-to-one trial results 3,56. Then small group evaluation trial result is 3,54. The overall results from all of the trials are the development of mortgage subsidy guide books is already very good.

\footnotetext{
$\square$ Corresponding author : Sharah Mulyani Adress: Universitas Negeri Jakarta

Jakata, Indonesia

E-mail: sharahmulyani11@gmail.com
} 


\section{PENDAHULUAN}

Pertumbuhan jumlah penduduk Indonesia mengalami peningkatan setiap tahunnya. Hal yang perlu diperhatikan oleh Pemerintah adalah kelayakan hidup warga negara Indonesia. Kebutuhan primer menjadi perhatian utama Pemerintah. Salah satu kebutuhan primer yang menjadi perhatian pemerintah adalah rumah yang layak bagi warga negara indonesia.

Pemerintah melalui Kementrian Pekerjaan Umum dan Perumahan Rakyat (PUPR) menggalakan program sejuta rumah bagi masyarakat berpenghasilan rendah. Masyarakat berpenghasilan rendah dapat membeli rumah dengan cara kredit pemilikan rumah (KPR) subsidi.

Dalam mewujudkan program sejuta rumah untuk warga Indonesia yang tergolong masyarakat berpenghasilan rendah, Kementrian PUPR bekerja sama dengan pengembang perumahan dan bank yang menyediakan KPR subsidi.

PT Tata Bangun Sarana merupakan sebuah perusahaan yang bergerak di bidang properti yakni, pengembang perumahan. Selain ditunjang dari kinerja pegawainya, menjadikan klien atau konsumennya sebagai mitra bisnis lewat kinerja yang baik merupakan salah satu hal yang dapat menunjang keberhasilan dari PT Tata Bangun Sarana.

Teknologi kinerja disini merupakan pendekatan yang sistematis untuk meningkatkan produktivitas dan kompetensi, menggunakan seperangkat metode, prosedur dan strategi untuk memecahkan masalah dengan mencari peluang yang berhubungan dengan kinerja manusia. (Organisasi Profesi ISPI, 2005)

Sebagai sebuah perusahaan, tentunya PT Tata Bangun Sarana harus memiliki strategi agar tetap dapat bertahan dan berkembang.
Strategi yang dapat dilakukan adalah dengan menciptakan berbagai inovasi baru dengan melihat pangsa pasar. Perusahaan juga harus mampu bersaing dengan para pengembang perumahan lainnya.

Pertumbuhan jumlah penduduk Indonesia menjadi perhatian pemerintah akan kebutuhan adanya tempat tinggal yang layak bagi warga masyarakat, terutama yang memiliki penghasilan menengah kebawah. Program sejuta rumah merupakan salah satu upaya yang dilakukan oleh pemerintah. Rumah Sejahtera Tapak atau yang lebih umum dikenal orang dengan rumah bersubsidi adalah Rumah Umum yang dibangun oleh orang perseorangan atau badan hukum dengan spesifikasi sama dengan rumah sederhana sebagaimana diatur dalam Keputusan Menteri Permukiman dan Prasarana Wilayah Nomor 403/KPTS/M/2002 tentang Pedoman Teknis Pembangunan Rumah Sederhana Sehat, Peraturan Menteri Negara Perumahan Rakyat Nomor 25 Tahun 2011 tentang Pedoman Penyelenggaraan Perumahan Murah, dan/atau Peraturan Perundang - undangan yang mengatur tentang pedoman teknis pembangunan Rumah Sejahtera. (Perumnas)

PT. Tata Bangun Sarana merupakan salah satu perusahaan pengembang perumahan di Indonesia. Meskipun tergolong sebagai perusahaan yang baru berdiri, namun PT Tata Bangun Sarana telah memiliki to lokasi proyek perumahan yang tersebar di daerah Bekasi dan sekitarnya. Perumahan tersebut ada yang khusus untuk rumah subsidi maupun nonsubsisdi dengan berbagai tipe. Dalam hal ini, PT. Tata Bangun Sarana dapat dikatakan telah berkontribusi dalam program sejuta rumah. Dalam memasarkan proyek perumahannya, PT Tata Bangun Sarana menjalin kerjasama dengan beberapa agent property yang menyediakan jasa sales.

Saat peneliti melakukan wawancara pada tanggal bulan februari 2017 dengan seorang pegawai di bagian administrasi PT Tata Bangun Sarana, hasil wawancara menunjukkan beberapa konsumen mempermasalahkan 
kejelasan status pembelian rumah KPR. Penyebab masalah tersebut terdiri dari dua faktor, yakni dari faktor konsumen dan faktor sales. Faktor pertama dari konsumen adalah mereka mengeluhkan sumber informasi dan pengetahuan mereka mengenai syarat dan ketentuan khusus pembelian rumah KPR subsidi kurang memadai, dan faktor kedua karena sales tidak fokus dalam melayani karena konsumen yang bisa berjumlah belasan orang dalam satu bulan, maka sales tidak dapat memberikan informasi yang lengkap kepada konsumen.

Selain itu, saat melakukan observasi kedua dengan mengikuti proses wawancara dan akad kredit di Bank BTN pada 24 Februari 2017, peneliti menemukan ada beberapa konsumen yang gugup saat diwawancarai sehingga menyebabkan petugas Bank yang mewawancarainya ragu untuk menindaklanjuti permohonan kredit yang diajukan oleh konsumen.

Dari beberapa masalah yang telah diungkapkan, agar konsumen dapat memperoleh informasi dan ketentuan yang dapat membantu mereka, salah satu caranya adalah dengan memfasilitasi belajar yang termasuk dalam bidang garapan teknologi pendidikan. Teknologi pendidikan bertujuan untuk memecahkan masalah dan meningkatkan kinerja dengan cara menciptakan, menggunakan, dan mengelola proses dan sumber teknologi yang sesuai dengan kebutuhan.

Peneliti memiliki gagasan untuk mengembangkan sebuah media cetak. Dengan sasaran yang telah spesifik, yakni konsumen pembeli rumah KPR subsidi yang membutuhkan sebuah media yang dapat menyampaikan informasi langsung dan mudah dipahami dengan cepat mengenai tahapan pembelian rumah KPR subsidi. Media cetak tersebut berupa buku panduan.
Buku panduan dipilih karena bentuknya lebih praktis, bisa digunakan tanpa bantuan alat lain. Kemudian, dengan perbedaan latar belakang pendidikan dan pekerjaan konsumen pembeli rumah KPR bersubsidi di PT. Tata Bangun Sarana yang berbeda-beda maka media yang paling umum yang dapat digunakan adalah berupa buku panduan.

Buku pedoman / buku panduan (manual) dan buku pegangan (handbook) termasuk bahan rujukan yang banyak dicari oleh pengguna perpustakaan. Nama kedua jenis terbitan ini seringkali digunakan secara bergantian dengan maksud yang sama. Umumnya diartikan bahwa kedua terbitan ini menyajikan informasi yang siap dalam bidang ilmu pengetahuan tertentu, biasanya untuk bidang - bidang ilmu yang sudah berkembang dengan baik, jadi bukan bidang ilmu yang masih baru berkembang.

Media cetak berupa buku panduan juga memiliki beberapa kelebihan, diantaranya ekonomis, dapat dibawa kemana-mana, dapat memungkinkan untuk dibaca berulang-ulang oleh konsumen. (Abdul dan Janti, 2009)

Buku panduan yang akan dikembangkan berisikan tentang tahapan yang harus dilalui oleh konsumen dalam pembelian rumah KPR bersubsidi, berkas-berkas dan aplikasi apa yang harus dilengkapi untuk pengajuan kredit di bank, aturan-aturan yang berlaku dari pengembang dan bank, persiapan untuk akad kredit hingga serah terima kunci rumah.

Contoh penelitian terdahulu mengenai buku panduan yang dapat memfasilitasi belajar adalah Pengembangan Media Cetak Panduan Praktis Beternak Lele untuk Pemula, yang ditulis oleh Abu Bakar Shodik mahasiswa Teknologi Pendidikan Universitas Negeri Jakarta pada tahun 2016 Penelitian pengembangan ini bertujuan untuk menghasilkan produk berupa media cetak dengan nama "Panduan Praktis Beternak Lele untuk Pemula". Penelitian yang dilaksanakan 
pada tempat pelatihan berterak lele yang dimiliki oleh seorang peternak ahli bernama Nasrudin yang berada di Kota Depok Jawa barat ini adalah untuk menghasilkan sebuah panduan yang dapat memfasilitasi para peternak pemula yang akan memulai ternak lele secara mandiri. Metode pengembangan yang digunakan dalam mengembangkan produk ini adalah menggunakan model ADDIE. Pada tahap uji coba one to one yang terdiri dari tiga orang responden hasil skor rata - rata 91,6\%. Tahap uji coba small grup terdiri dari delapan responden yang mewakili dari kondisi sebelum dilakukannya uji coba sebenarnya dan mendapat skor rata- rata 94\%. Tahap uji coba yang terakhir adalah tahap uji coba field test pada tahapan ini dilakukan uji coba sebenarnya kepada lima belas orang responden peternak pemula yang sedang melakukan pelatihan ternak lelel dan mendapat skor 94\%. Hasil penelitian pengembangan panduan yang berbentuk media cetak ini dapat membantu pengguna saat mulai beternak secara mandiri dan instruktur dalam penyampaian materi beternak lele.

Maka pengembang berharap penelitian pengembangan buku panduan pembelian rumah KPR subsidi ini juga dapat membantu konsumen secara maksimal.

\section{METODE}

Penelitian pengembangan ini dilakukan di PT. Tata Bangun Sarana pada bulan Januari sampai mei 2018. Dengan mengembangkan model pembelaran Rowntree. Pengumpulan data dilakukan kepada 1 orang ahli materi, 1 orang ahli media, 3 orang untuk one to one evaluation dan 9 orang untuk small group evaluation.

Instrumen penelitian dibuat berdasarkan kisi-kisi yang dikembangkan berdasarkan komponen-komponen dan prinsip desain pesan dalam pengembangan buku panduan. Kategori penliaian menggunakan skala likert, sangat baik, baik, cukup baik dan kurang baik.
Penelitian

pengembangan

ini dikembangkan menggunakan model pengembangan Rowntree yang berisi tiga tahapan diantaranya, (1) Tahap Perencanaan, (2) Tahap Persiapan Penulisan, (3) Tahap Penulisan dan Penyuntingan.

\section{HASIL DAN PEMBAHASAN}

Penelitian pengembangan ini telah dilaksanakan. (1) Penelitian dimulai pada bulan januari 2018. (2) Membutuhkan waktu kurang lebih 1 bulan. (3) Melibatkan seorang ahli materi, seorang ahli media dan 9 orang konsumen KPR subsidi (4) Berikut ini hasil pengembangan Buku Panduan yang menggunakan model pengembangan Rowntree.

\section{A. Deskripsi Hasil Pengembangan}

Model pengembangan Rowntree ini terdiri dari 3 Tahapan yakni, tahap perencanaan, tahap persiapan penulisan, dan tahap penulisan dan penyuntingan.

Pada tahap perencanaan didapatkan data konsumen sebagai berikut.

Tabel 1 Daftar Nama Pengguna Buku Panduan

\begin{tabular}{clll}
\hline No. & Nama & Usia & Pekerjaan \\
\hline $\mathbf{1}$ & Bagus & $\mathbf{2 8}$ & Karyawan \\
$\mathbf{2}$ & Nur & 43 & Wiraswasta \\
$\mathbf{3}$ & Hendra A. & $\mathbf{2 4}$ & Wiraswasta \\
$\mathbf{4}$ & Alfred & 47 & Karyawan \\
$\mathbf{5}$ & Sinawati & 32 & Karyawan \\
$\mathbf{6}$ & Erwin Gayo & $\mathbf{2 3}$ & Karyawan \\
$\mathbf{7}$ & Moh. Basri & 43 & Karyawan \\
$\mathbf{8}$ & Indra & $\mathbf{2 8}$ & Konsultan \\
& & & Hukum \\
$\mathbf{9}$ & Habibul Ahyar & $\mathbf{2 5}$ & Karyawan \\
\hline
\end{tabular}

Tabel 1 merupakan hasil data pengguna berdasarkan faktor demografi.

Kemudian dalam tahap perencanaan, yang dilakukan adalah mempertimbangkan sumber-sumber daya dan hambatan, mengurutkan ide dan gagasan, mengumpulkan contoh-contoh terkait, penentuan grafis, mempersiapkan peralatan yang dibutuhkan serta menentukan format fisik dari Buku Panduan KPR Subsidi.

Tabel 2 Spesifikasi Buku Panduan 


\begin{tabular}{|c|c|c|}
\hline 1 & Ukuran Buku & $\mathrm{B}_{5}(18,2 \mathrm{~cm} \times 25,7 \mathrm{~cm})$ \\
\hline 2 & Kertas Cover & Art Carton 2oogram \\
\hline 3 & Isi & HVS 10ogram \\
\hline 4 & Halaman & 5 \\
\hline 5 & Warna & Full Colour \\
\hline \multicolumn{3}{|c|}{$\begin{array}{l}\text { terakhir dari model } \\
\text { lah tahap penulisan dan } \\
\text { tahap ini dilakukannya uji } \\
\text { buku panduan yang } \\
\text { kut hasil uji coba dari ahli }\end{array}$} \\
\hline
\end{tabular}

\section{Tabel 3 Uji Coba Ahli Materi}

\begin{tabular}{|c|c|}
\hline Pernyataan & Nilai \\
\hline Kelengkapan komponen & 3 \\
\hline Urutan penyajian komponen & 4 \\
\hline Kesesuaian materi & 4 \\
\hline Kejelasan materi & 4 \\
\hline Materi disampaikan secara sistematis & 4 \\
\hline Kesesuaian contoh dengan materi & 4 \\
\hline Kecukupan materi yang disajikan & 3 \\
\hline 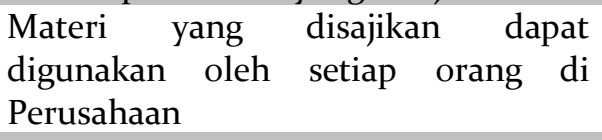 & 4 \\
\hline Kejelasan bahasa yang digunakan & 4 \\
\hline Ketepatan penulisan ejaan & 4 \\
\hline Kejelasan struktur kalimat & 3 \\
\hline Kesesuaian gaya bahasa & 4 \\
\hline Ketepatan Penggunaan tanda baca & 3 \\
\hline Konsistensi tata letak (layout) & 4 \\
\hline Kejelasan ilustrasi & 4 \\
\hline Kesesuaian ilustrasi dengan materi & 4 \\
\hline Daya tarik ilustrasi & 3 \\
\hline Rata-Rata & 3,7 \\
\hline
\end{tabular}

Berdasarkan hasil dari uji coba ahli materi yang terdapat pada tabel 3, nilai ratarata yang didapatkan pengembang adalah 3,7. Maka jika dilihat dari skala penilaian produk yang memiliki rentang nilai 1-4, buku panduan ini masuk ke dalam kategori sangat baik. Sehingga dapat pengembangan simpulkan bahwa buku panduan KPR subsidi ini dapat membantu konsumen untuk melewati proses tahapan KPR subsidi dengan baik.

Ahli Materi juga memberikan beberapa saran, diantaranya:

(1) Lengkapi dengan status legalitas rumah subsidi (sertifikat SHGB dan masa berlakunya). Sertifikat tersebut dapat ditingkatkan menjadi hak milik.

(2) Jelaskan tentang definisi/pengertian istilah dari akad kredit (perbankan) yang tidak dipahami oleh masyarakat umum.

Revisi yang dilakukan oleh pengembang adalah menambahkan materi mengenai pengertian akad kredit dan menambahkan pokok bahasan mengenai sertifikat

\section{Tabel 4 Uji Coba Ahli Media}

\begin{tabular}{|c|c|}
\hline Pernyataan & Nilai \\
\hline Kelengkapan komponen & 3 \\
\hline Urutan penyajian komponen & 3 \\
\hline Kejelasan materi & 4 \\
\hline Kecukupan materi yang disajikan & 4 \\
\hline Kejelasan bahasa yang digunakan & 3 \\
\hline Ketepatan penulisan ejaan & 3 \\
\hline Kejelasan struktur kalimat & 3 \\
\hline Kesesuaian gaya bahasa & 4 \\
\hline Ketepatan Penggunaan tanda baca & 3 \\
\hline Konsistensi tata letak (layout) & 3 \\
\hline Kejelasan ilustrasi & 3 \\
\hline Kesesuaian ilustrasi dengan materi & 4 \\
\hline Daya tarik ilustrasi & 4 \\
\hline $\begin{array}{l}\text { Kesesuaian margin dengan badan } \\
\text { buku }\end{array}$ & 4 \\
\hline Daya tarik cover & 3 \\
\hline Ketepatan proporsi warna & 3 \\
\hline $\begin{array}{l}\text { Ketepatan pemilihan warna dengan } \\
\text { fungsi dalam materi }\end{array}$ & 3 \\
\hline Pemilihan jenis huruf & 3 \\
\hline $\begin{array}{l}\text { Ketepatan pemilihan warna dengan } \\
\text { fungsi dalam materi }\end{array}$ & 4 \\
\hline Penekanan dengan gaya huruf & 3 \\
\hline Kesesuaian ukuran spasi & 0 \\
\hline Kesesuaian ukuran buku panduan & 4 \\
\hline Pemilihan jenis dan kualitas kertas & 3 \\
\hline Kejelasan cetakan & 4 \\
\hline Rata-Rata & 3,37 \\
\hline
\end{tabular}

Nilai rata-rata yang didapatkan dari hasil uji coba ahli media adalah 3,37

Berdasarkan skala penilaian produk yang memiliki rentang nilai 1-4, buku panduan ini termasuk kedalam kategori sangat baik. Maka dapat disimpulkan bahwa Buku Panduan KPR Subsidi dapat membantu konsumen dalam melewati tahapan pengajuan KPR subsidi. 
Beberapa saran yang diberikan ahli media adalah sebagai berikut, (1) Perbaiki cover / komposisinya, (2)Cetak pada kertas 100-120 gram, (3) Tambahkan sumber gambar.

Revisi yang dilakukan oleh pengembang adalah mengganti desain cover buku panduan, mencetak buku panduan dengan jenis kertas 190 gram dan menambahkan sumber gambar di bagian daftar pustaka.

Berikut ini merupakan perbaikan desain pada buku panduan berdasarkan saran dari ahli media.

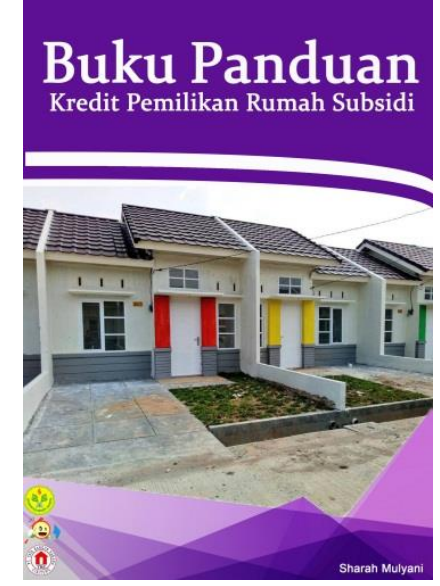

\section{Gambar 1 Cover Sebelum Revisi}

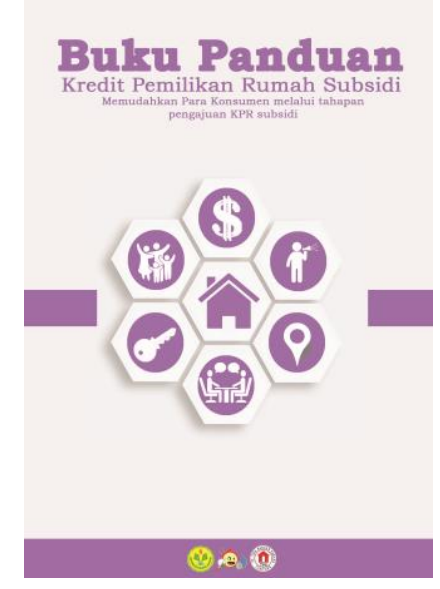

\section{Gambar 2 Cover Setelah Revisi}

Selain cover ada beberapa layout isi dari buku panduan KPR subsidi yang pengembang ubah setelah melakukan konsultasi dengan pembimbing.

\section{Tabel 5 Uji Coba One to One}

\begin{tabular}{|c|c|c|c|}
\hline \multirow{2}{*}{ Pernyataan } & \multicolumn{3}{|c|}{ Nilai } \\
\hline & Indra & Habib & Basri \\
\hline $\begin{array}{l}\text { Kesesuaian urutan } \\
\text { penyajian materi }\end{array}$ & 3 & 4 & 3 \\
\hline $\begin{array}{l}\text { Kesesuaian materi } \\
\text { dengan pengguna }\end{array}$ & 3 & 3 & 3 \\
\hline $\begin{array}{lrr}\text { Materi yang } & \text { disajikan } \\
\text { memadai } & \text { kebutuhan } \\
\text { pengguna } & \end{array}$ & 4 & 3 & 4 \\
\hline $\begin{array}{lrr}\text { Materi yang } & \text { disajikan } \\
\text { dapat } & \text { memabantu } \\
\text { pengguna } & \end{array}$ & 4 & 4 & 4 \\
\hline $\begin{array}{l}\text { Kejelasan bahasa yang } \\
\text { digunakan }\end{array}$ & 4 & 4 & 4 \\
\hline $\begin{array}{l}\text { Penggunaan ejaan yang } \\
\text { tepat }\end{array}$ & 4 & 4 & 4 \\
\hline $\begin{array}{l}\text { Kesesuaian ilustrasi } \\
\text { dengan kebutuhan }\end{array}$ & 3 & 4 & 4 \\
\hline $\begin{array}{l}\text { Daya tarik warna dalam } \\
\text { buku }\end{array}$ & 3 & 4 & 3 \\
\hline $\begin{array}{l}\text { Ilustrasi materi terhadap } \\
\text { daya tarik pengguna }\end{array}$ & 3 & 3 & 3 \\
\hline Daya tarik cover & 3 & 4 & 4 \\
\hline Ukuran Buku & 4 & 4 & 3 \\
\hline $\begin{array}{l}\text { Pemilihan jenis dan } \\
\text { kualitas kertas }\end{array}$ & 3 & 3 & 4 \\
\hline Rata-Rata & 3,42 & 3,67 & 3,58 \\
\hline Rata-Rata Keseluruhan & & 3,56 & \\
\hline
\end{tabular}

Nilai rata-rata yang didapatkan dari hasil uji coba one to one adalah 3,56. Berdasarkan skala penilaian produk yang memiliki rentang nilai 1-4, buku panduan ini termasuk kedalam kategori sangat baik.

\section{Tabel 6 Uji Coba Small Group}

\begin{tabular}{llcl}
\hline No & \multicolumn{2}{l}{ Nama Konsumen } & \multicolumn{1}{l}{ Skor Rata-rata } \\
\hline & & Tim 1 \\
$\mathbf{1}$ & Nur & & 3,5 \\
$\mathbf{2}$ & Hendra A. & 3,8 \\
$\mathbf{3}$ & Alfred & 3,75 \\
& & Tim 2 & \\
$\mathbf{1}$ & Sinawati & 3,67 \\
$\mathbf{2}$ & Erwin & 3,67 \\
\hline
\end{tabular}


Sharah Mulyani | JPI/Vol.o2/No.o1/2019| H. 32-39

\begin{tabular}{llll}
\hline $\mathbf{3}$ & Bagus & 3,5 & Tahap pertama yaitu tahapan \\
& Rata-rata & $\mathbf{3 , 6 4}$ & perencanaan, didalam tahap ini terdapat
\end{tabular}

Nilai rata-rata yang didapatkan dari hasil uji coba Small group adalah 3,64. Berdasarkan skala penilaian produk yang memiliki rentang nilai 1-4, buku panduan ini termasuk kedalam kategori sangat baik.

\section{B. Prosedur Pemanfaatan Produk}

Buku panduan KPR subsidi yang telah dikembangkan memiliki pendahuluan dan petunjuk penggunaan buku panduan. Sebelum mempelajari buku panduan, pengguna buku panduan disarankan untuk membaca terlebih dahulu pendahuluan dan petunjuk penggunaan buku panduan.

Pengguna buku panduan disarankan untuk mempelajari secara berurutan dimulai dari bagian 1 mengenai KPR Subsidi sampai dengan bagian ke 5 yaitu materi mengenai Pelunasan dan Sertifikat, agar tercapainya tujuan pembelajaran. Di dalam buku panduan ini terdapat lembar ceklis yang dapat digunakan oleh pengguna untuk melakukan pengecekan ulang berkas persyaratan kredit yang akan diajukan.

\section{Keterbatasan Pengembangan}

Pertama, Melakukan uji coba One to One secara random, seharusnya dapat dipilih berdasarkan latar belakang pendidikan.

Kedua, Intensitas konsultasi dengan ahli untuk membahas mengenai buku panduan yang dikembangkan sehingga ada beberapa materi yang dirasa masih kurang maksimal.

Ketiga, Keterbatasan waktu untuk mengumpulkan konsumen dan sulitnya mendapatkan umpan balik sehingga Field Test tidak dapat dilaksanakan.

\section{SIMPULAN}

Berdasarkan prosedur pengembangan yang dilakukan maka diperoleh hasil sebagai berikut:

beberapa tahapan yaitu menentuan profil pengguna buku panduan, merumuskan tujuan umum dan tujuan khusus, menyusun garis besar isi serta menentukan media yang akan dikembangkan. Pada tahap ini pengembang merencanakan pendukung belajar dan mengembangkan media dengan mempertimbangkan dari bahan belajar yang telah ada sebelumnya. Hasil dari tahapan ini berupa rancangan rumusan pembelajaran yang berisi tujuan pembelajaran, materi, serta media yang akan digunakan oleh konsumen.

Tahap kedua yaitu tahap persiapan penulisan, tahapan ini meliputi mempertimbangkan sumber daya dan hambatannya, mengurutkan ide atau gagasan, menentukan grafis pendukung yang sesuai, menentukan peralatan yang dibutuhkan dan menentukan format fisik. Pada tahap ini pengembang dapat menghasilkan rumusan contoh gambar atau ilustrasi, umpan balik, bentuk fisik buku panduan serta peralatan yang dibutuhkan sampai pada proses pencetakan buku panduan.

Dan tahap ketiga adalah tahap penulisan dan penyuntingan. Pada tahap ini terdapat beberapa tahapan yaitu memulai membuat draft, melengkapi dan menyunting draft, menulis penilaian belajar dan menguji coba serta memperbaiki. Hasil dari tahap ini adalah draft buku panduan yang didalamnya telah terdapat gambar atau ilustrasi, umpan balik, pendahuluan, kata pengantar dan isi materi yang disajikan dalam buku panduan. Ujicoba yang dilakukan terdiri dari ujicoba ahli, ujicoba one to one dan ujicoba Small Group Evaluation.

Hasil dari ujicoba ahli dan pengguna buku panduan dapat disimpulkan berdasarkan skala penilaian yang ditetapkan. Berikut ini hasil nilai yang didapat: 
(1) Ujicoba Ahli Materi 3,7 maka dapat dikategorikan sangat baik. (2) Ujicoba Ahli Media 3,37 maka dapat dikategorikan sangat baik. (3) Ujicoba One To One 3,56 maka dapat dikategorikan sangat baik. (4) Ujicoba Small Group Evaluation 3,64 maka dapat dikategorikan sangat baik.

Berdasarkan dari hasil penelitian yang telah diuraikan diatas maka dapat disimpulkan bahwa buku panduan pengajuan KPR subsidi dapat diterima dengan baik oleh pengguna, ahli materi dan ahli media.

Saran serta masukan yang diberikan telah diterima dan diperbaiki oleh pengembang untuk menyempurnakan buku panduan ini. Sehingga buku panduan ini dapat digunakan untuk membantu seorang konsumen yang akan melakukan tahapan pengajuan KPR subsidi.

Berikut ini saran yang dapat diberikan dari hasil penelitian pengembangan ini adalah,

(1) Dapat dilakukan penelitian lebih lanjut dengan melakukan uji coba Field Test Evaluation menggunakan Buku Panduan KPR Subsidi. (2) Mahasiswa yang ingin melakukan penelitian pengembangan, dapat membuat Panduan tips \& trik dalam kegiatan wawancara. (3) File Buku Panduan ini diunggah ke dalam website www.tatabangunsarana.com sehingga konsumen atau sales dapat mengakses secara bebas dan mencetak sesuai kebutuhannya.

\section{UCAPAN TERIMA KASIH}

Terima kasih kepada Ibu Suprayekti dan Ibu Retno Widyaningrum yang telah memberikan saran serta dukungan pengetahuan dan informasi kepada peneliti dalam membuat penelitian ini sampai dengan selesai. Terima kasih kepada Bapak Iswantoro selaku ahli materi dan Bapak Cecep Kustandi selaku ahli media yang telah meluangkan waktunya untuk memberika nilai serta saran.

\section{DAFTAR PUSTAKA}

Baker, Robert L. dan Schultz, Richard E, (1971) Instructional Product Development. New York: Van Nostrand Reinhold Co.

Piskurich, George M.( 200o) The ASTD Handbook of Training Design and Delivery. New York: McGraw-Hill.

Prawiradilaga, Dewi S. (2012) Prinsip Disain Pembelajaran. Jakarta: Kencana Prenada Media Group.

Prawiradilaga, Dewi S. (2012) Wawasan Teknologi Pendidikan. Jakarta: Penerbit Kencana.

Rowntree, D. (1994) Preparing materials for open, distance, and flexible learrning. London: Kogan Page.

UNDANG-UNDANG REPUBLIK INDONESIA NOMOR 20 TAHUN 2003

UNDANG-UNDANG REPUBLIK INDONESIA NOMOR 4 TAHUN 2016 